\title{
Investment and Government Expenditure and Investment Economic Growth in Central Java, Indonesia
}

\author{
Sri Isnowati ${ }^{1}$, Mulyo Budi Setiawan ${ }^{2}$ Basukianto $^{3}$, Wardjono $^{4}$ \\ ${ }_{1,2,3,4}$ Economic and Business Faculty \\ Univesitas Stikubank \\ Semarang, Indonesia
}

isnowati @edu.unisbank.ac.id

\begin{abstract}
The role of government expenditure in economic growth is very important. The aim of this paper was to study the government expenditure and investment on economic growth in Central Java. The data used was the secondary data from 2000.1 to 2018.4. The analysis tool used was Error Correction Model (ECM). The test of cointegration testing used Johansen test of cointegration which was used to test the presence of a long-term relationship in the variables economic growth, expenditure approach and investment. The analysis results using the regression method of Error Correction Model indicate that the effect of the variable of government expenditure on output is positive and significant, both in the short and long term.
\end{abstract}

Keywords: Government Expenditure, Investment, Economic Growth, ECM

\section{INTRODUCTION}

Economic growth as a process of increasing output over time becomes an important indicator to measure the success of a country's development (1). Therefore, the identification of various influencing factors including the roles of government is interested to be studied more deeply.

One study that examined the roles of public sector to economic growth is Wagner which was then known as Wagner Law. In Wagner Law, the hypothesis is that government expenditure increases economic activity. The theory holds that for any country, that public expenditure rises constantly as income growth expands. The law predicts that the development of anindustrial economy will be accompanied by an increased share of public expenditure in grossnational product.The basic idea is that goods and services are generally provided by the government sector, including the redistribution through transfers and the activities of public companies that generate greater income levels(2). The school of economics that explains the roles of public sector on economic growth is Keynesian. Keynes said that government expenditure would accelerate economic growth.

The relationship between economic growth and government expenditure, or more commonly the size of the public sector, becomes the important object to be analyzed and debated. The first controversy is whether the public sector can raise the long run steady state growth economy. In general,the depiction of public expenditures, namely physical infrastructure or human capital, can enhance growth. However, in financial sector, expenditure can particularly slow down the growth because of disincentive effect. In general, the impact depends on the trade-off between productive public expenditure and tax effects which are distortive.

Government expenditure as a real form of government intervention in economy has become an important object for the study. The studiesin European countries wereconducted by(3). (3) proved the positive and significant effect of government expenditure on economic growth in the UK, Germany and Ireland. The other research also showed that the expansion of government expenditure has positive effect on economic growth, such as the research of(4). On the other hand, there were also the studies that showed the significance of the relationship between both variables but with a pattern of relationships which tends to be negative. The research was conducted by (5)and(6).

The aim of this research was to evaluate empirically the effect of government expenditure on economic growth in Central Java. The structures of the paper are as follows: The second section discusses the literature review, the third section 
discusses the methodology used in the research, the fourth section discusses the research results, and the fifth section is the conclusion.

\section{LITERATURE REVIEW}

From the research results, it was found that the roles of government expenditure to economic growth have no uniformity. There werestudies showingthat the roles of government expenditure on economic growth have negative effects. On the other hand, there were studiesshowing that the roles of government expenditure on economic growth are positive.

The research results showing that government expenditureshave negative effect on economic growth were the research conducted by(6), (7).

In contrast to the previous studies which stated that government expenditure has negative effect on economic growth, there werethe other researchers who argue that government expenditure has positive effect on economic growth since the state through policies can create productive sectors so as to encourage economic growth and can also reduce the unproductive sectors. The researches showing that government expenditure has positive effect on economic growth were conducted (2), (8), and (7), (9), (10).

\section{RESEARCH METHOD}

In this research, the data used were the secondary data published by the Central Statistics Agency (BPS). The data used were in the form of quarterly data from 2004.1 to 2018.4.

The empirical model used in this research was: $d(g)=\beta_{0}+\beta_{1} d\left(E_{t}\right)+\beta_{2} d\left(I_{t}\right)+\beta_{3} E_{t}(-1)+$ $\beta_{4} I_{t}(-1)+E C$

Where:g is economic growth, $E_{t}$ is government expenditure, $I_{t}$ is investment, $\varepsilon_{t}$ is the residual value, and EC isError Correction Term.

The empirical analysis in this research is as follows; first, the root unit test was used to test data stationary. Secondly, cointegration testing was used to examine the long-term relationship of the variables of government expenditure, investment and output levels. Third, the analysis of the dynamic relationship between government expenditure, investment and output level was conducted using Error Correction Model.

\section{RESULTS AND DISCUSSION}

After testing the unit root with the level of confidence of 5 per cent,the variable used in the research (LG, LE, LI) which is not stationary at zero degrees of $\mathrm{I}(0)$ is $\mathrm{L}(\mathrm{I})$. Therefore, the integration level test was conducted to determine in whatlevel the observed variables are stationary.
Next,the data was made to be stationaryby first differencing. As the result, all the variables are stationary (integrated) in the first differencing of $\mathrm{I}(1)$.

The next step was test of cointegration test. The test of cointegration testing used Johansen test of cointegration which was used to test the presence of a long-term relationship in the variables LG, LE and LI. The result is that there is a cointegration between the variables in the long term.

The analysis results using the regression method of Error Correction Model indicate that the effect of the variable of government expenditure on output is positive and significant, both in the short and long term. It supports the hypothesis of Wagner law that government expenditure has positive effect on output growth of. For the variable of investment, the results of regression analysis show positive effect in both the short and long term.

The collective testing showed that the variables of government expenditure and investment has theeffect on output. The value ofthe output variation that can be explained by the variables of government expenditure and investment is 0.7435 .

This result supports the Keynesian model. Based on the findings of the empirical analysis, the study recommends that capital government expenditure should be directed mainly to current productive economic activities in order to stimulate activities in the economic sectors

\section{CONCLUSION}

From the analysis results, it can be concluded that:

1. The variable of government expenditure has positive effect on output in the short term and long term.

2. The variable of investment has positive effect on output in the short term and long term.

\section{Policy Implications}

In Central Java, the role of government expenditure to output level of output is positive. This means that government expenditure is still needed to stimulate economic growth, particularly to encourage productive sectors.

\section{REFERENCES}

[1]Todaro, M.P."Economic development in the Third Word."New York : Longman, 2005.

[2]Turrini, Alfonso Arpaia and Alessandro. "Government Expenditure and Economic Growth in the EU: Long-Run Tendencies and Short-Term Adjustment."European Economic Paper, 2008.

[3]Loizides, John and George Vamvoukas. "Government Expenditure And Economic Growth: Evidence From 
Trivariate Causality Testing." Journal Of Applied Economics, pp. 125-128, 2005.

[4]Singh, S.K.Public Finance in Theory and Practice. s.1. : S. Chand, 2008.

[5]Landau, D."Government Expenditure and economic Growth." Southern Economic Journal, pp. 783-792, 1986.

[6]A. Nurudeen, Abu. "Government Expenditure And Economic Growth In Nigeria, 1970-2008."Business and Economics Journal, pp. 1-10, 2010.

[7]Wu, Shih Ying. "The impact of government expenditure on economic growth: How sensitive to the level of development?" Journal of Policy Modelng, pp. 804-817, 2010.

[8]Alexiou, Constantinos."Government Spending and Economic Growth: Econometric Evidence from the South Eastern
Europe (SEE)."Journal of Economic and Social Research , pp. 1-16, 2009.

[9]Lee, Jhong Can."Government Expenditure and Economic Growth in the EU: Long-Run Tendencies and ShortTerm Adjustment." Sustainability, 2019.

[10]Al-Fawwaz, Torki M. "The Impact of Government Expenditures on Economic Growth in Jordan 19802013."International Business Research, pp. 99-105, 2016.

[11]landau, D. "Government Expenditure and economic Growth: A Cross Country Study."Southern Economic Journal, pp. 783-792, 1983.

[12]Ghura, Dhaneswara."Growth in Sub Saharan Africa." IMF Working paper, p. 136, 1995. 